\title{
SIKAP SOSIAL KEAGAMAAN ROHIS DI SMA PADA DELAPAN KOTA DI INDONESIA
}

\author{
Achmad Habibullah \\ Peneliti pada Puslitbang Pendidikan Agama \& Keagamaan \\ Jalan M. H. Thamrin Nomor 06 Jakarta \\ puslitbangpenda@yahoo.co.id
}

\begin{abstract}
The opinion from studies on religious aspects of senior high school Islamic club summarized in this paper is important considering as lately there is a stronger tendency that Islamic club at school has became a religious movement that is spreading inclusive religious social attitudes. At the beginning of its formation, Islamic club is expected to be the arena for development of Islamic religious knowledge and insight for students that are not sufficiently explored in the activities of Islamic religious education lessons in the classroom. The study used a qualitative approach with in-depth interviews as the main instrument in eight cities in Indonesia, and seeks like to see the social religious attitudes of Islamic club activists associated with aspects of Islam in social life, Islam in the political life of the state, and Islam in gender equality. The findings show that in general high school Islamic club activists are more open and tolerant in neighboring life, but they expect the Islamic system can be the foundation. There is also a tendency that high school Islamic club activists expect that islam can be the foundation of our state system, in which the Islamic system of government (Khilafah Islamiyah) is the best alternative on the democratic system that has drawbacks. High school Islamic club activists in high school tend to put women in a subordinate position of men in both the domestic and the public sphere.
\end{abstract}

Keywords: islamic club, social attitudes, politics, gender equality

\begin{abstract}
Abstrak
Tulisan yang diangkat dari sebagian hasil penelitian tentang Keagamaan Rohis SMA yang terangkum dalam makalah ini menjadi penting dipaparkan mengingat akhir-akhir ini semakin menguatnya kecenderungan organisasi Rohis di sekolah menjadi sebuah gerakan keagamaan yang menyebarluaskan sikap sosial keagamaan yang insklusif. Pada awal pembentukannya diharapkan Rohis menjadi wadah pengembangan pengetahuan dan wawasan keberagamaan Islam yang ekslusif peserta didik yang kurang tergarap pada kegiatan-kegiatan pembelajaran pendidikan agama Islam di kelas. Penelitian tersebut menggunakan pendekatan kualitatif dengan metode wawancara mendalam sebagai instrumen utamanya, yang dilakukan pada delapan kota di Indonesia, ingin melihat sikap sosial keagamaan aktivis Rohis yang berkaitan dengan aspek Islam dalam kehidupan sosial, Islam dalam kehidupan politik kenegaraan, dan Islam dalam keseteraan jender. Temuannya menunjukkan bahwa pada umumnya aktivis Rohis SMA lebih bersikap terbuka dan toleran dalam kehidupan bertetangga, namun berharap sistem Islam dapat menjadi landasannya. Terdapat juga kecenderungan aktivis Rohis mengharapkan Islam menjadi landasan sistem kenegaraan, di mana sistem pemerintahan Islam (Khilafah Islamiyah) menjadi alternatif terbaik atas sistem demokrasi yang dipakai yang dinilai terdapat kekurangannya (mudharat). Terlihat juga kecenderungan aktivis Rohis di SMA yang bersikap menempatkan perempuan dalam posisi yang subordinatif dari laki-laki baik di ranah domestik maupun publik.
\end{abstract}

Kata Kunci: rohis, sikap sosial, politik kenegaraan, kesetaraan jender

Naskah diterima 2 Oktober 2014. Revisi pertama, 2 November 2014. Revisi kedua, 15 November 2014 dan revisi terakhir 1 Desember 2014. 


\section{PENDAHULUAN}

Berbagai pemberitaan di media massa mensinyalir bahwa Rohis (Rohani Islam) yang merupakan wadah pengembangan keagamaan Islam peserta didik di sekolah, telah menjadi tempat persemaian faham radikalisme dari kelompok-kelompok keagamaan radikal yang menyusup dalam kegiatan-kegiatan Rohis di sekolah-sekolah. Temuan beberapa penelitian yang dilakukan terkait dengan hal tersebut seperti yang dilakukan oleh LaKIP (Lembaga Kajian Islam dan Perdamaian) memang memperlihatkan adanya kecenderungan radikalisme di kalangan siswa SMA, walaupun dari siswa yang berkecenderungan radikalisme tersebut, hanya sebagian kecil merupakan aktivis Rohis. ${ }^{1}$

Tidak dapat dipungkiri kegiatan-kegiatan keagamaan yang diselenggarakan Rohis telah menjadi daya pikat dan magnet bagi beberapa peserta didik yang ingin memperdalam pengetahuan dan wawasan ke-islamannya. Hal tersebut ditunjukkan dengan semakin beragamnya kegiatan-kegiatan keagamaan yang dikemas Rohis. Mengapa kemunculan Rohis menjadi begitu fenomenal, karena dalam waktu relatif singkat telah menunjukkan eksistensinya di lingkup lembaga pendidikan yang namanya sekolah?

Berbagai hal dapat menjadi penyebab begitu hidup dan eksisnya Rohis di sekolah. Diantaranya, dalam proses pembelajaran di kelas, sebagian guru menggunakan metode pembelajaran yang kurang memadai. Sebuah riset yang dilakukan Program Studi Agama dan Lintas Budaya UGM, Jogjakarta

${ }^{1}$ Survei terbatas dilakukan LaKIP pada tahun 2010 mencakup 10 wilayah di Jabodetabek (lima kota di DKI Jakarta, Kota Bogor, Kota Depok, Kabupaten Tangerang, Kota Tangerang Selatan, dan Kota Bekasi) melihat kecil kemungkinan semaraknya faham radikalisme dipicu oleh kegiatan Rohis. Kecenderungan radikalisme tersebut dilihat dari dukungan siswa terhadap tindakan kekerasan berkaitan dengan isu-isu agama. Walaupun belum bertindak radikal, tetapi kesediaan mendukung terhadap tindakan kekerasan atas isu-isu agama hal itu sudah dikategorikan memiliki kecenderungan faham radikalisme. mendapati pembelajaran pendidikan agama di sekolah selain tidak memadai dari banyak segi (kurang kontekstual tapi lebih tekstual, lebih banyak menggunakan metode ceramah yang monoton dan membosankan peserta didik untuk menyimak, dan sebagainya), juga bersifat sangat eksklusif. Pengembangan sikap eksklusif tersebut terlihat pada arah pembelajaran yang lebih bersifat dogmatik. Hal tersebut tidak hanya terjadi dalam konteks pembelajaran Pendidikan Agama Islam saja, tetapi juga terjadi pada guru-guru pendidikan agama lainnya, seperti pada pemebelajaran Pendidikan Agama Kristen. Sebagian guru agama Kristen di wilayah tersebut selalu terpaku pada pola pikir yang cenderung melihat bahwa pelajaran agama di Sekolah tidak jauh berbeda dengan pelajaran sekolah minggu di gereja. Sehingga dalam konteks ini, selain diajarkan ragam nyanyian rohani, peserta didik kebanyakan hanya di pandu untuk menghafalkan pengakuan iman, dan sedikit sekali di arahkan untuk memahami makna ajaran yang terkandung didalamnya. ${ }^{2}$

Temuan dari Insitut Interfidei, Yogyakarta, memperkuat citra profil guru pendidikan agama seperti itu, yaitu sebagian besar guru pendidikan agama selalu berkutat pada masalah klasik demi memperkuat identitas keagamaannya masing-masing. Kebanyakan para guru tersebut menjalankan aktifitas ritual keagamaan dalam kerangka lahiriah yang formalistik, yang mensyaratkan bahwa pola pengajaran agama harus diarahkan pada upaya memperkuat identitas kegamaan. ${ }^{3}$ Deskrispi tersebut tentu saja semakin menegaskan bahwa alih-alih menyuburkembangkan atmosfer multikulturalisme yang memiliki sebarannya pada sikap toleran dan pluralis para insan akademis, sebagian besar guru pendidikan agama justru terjebak

2 Lihat, Laporan Tahunan Kehidupan Beragama di Indonesia Tahun 2008, (CRCS UGM, 2008), dalam, http:// www.crcs.ugm.ac.id/

${ }^{3}$ Lihat, Listia,dkk, Problematika Pendidikan Agama di Sekolah, Hasil Penelitian Tentang Pendidikan Agama di Kota Jogyakarta 2004-2006, (Istitut Dian/Interfidei, 2007). 
pada sekat aliran yang selanjutnya diketahui bernama fundamentalisme. ${ }^{4}$ Pada akhirmya, fundamentalisme akan menjadi lahan subur untuk berkembangnya sikap-sikap dan perilaku keagamaan yang radikal.

Begitupun dari sisi kurikulum yang tersedia ataupun bahan ajar yang digunakan baik oleh para guru maupun peserta didik di berbagai sekolah, nyatanya juga sangat kuat mempengaruhi kondisi tersebut. Secara subtansi, materi-materi yang dimunculkan di buku bahan ajar, terutama pada buku bahan ajar Pendidikan Agama Islam terkesan masih sangat formalistik-ritualistik dan menekankan nuansa normatif. Misalnya, materi akidah disampaikan melalui pendekatan teologisteosentris, bukan teologis antroposentris yang justru dibutuhkan peserta didik guna menumbuh-kembangkan sikap inklusif dan pluralis bagi tata kehidupan mereka kemudian di masyarakatnya. Begitupun dengan muatan pembelajaran Ibadah terlihat cenderung formalistik-ritualistik.

Keberlangsungan pembelajaran pendidikan agama yang demikian itu kemungkinan akan bersifat ganda. Pada satu sisi mempertebal semangat komitmen keagamaan peserta didik, namun pada sisi lain juga dikhawatirkan akan memperkuat semangat fanatisme beragama bagi peserta didik. ${ }^{5}$

Satu lagi faktoryang kemungkinan menjadi sebab semakin hidup dan eksisnya kegiatankegiatan keagamaan yang diselenggarakan

${ }^{4}$ Term ini sederhananya dipahami sebagai sebuah keyakinan yang berupaya menjaga keteguhan prinsipprinsip dasar agama serta cenderung melihat ide-ide multikulturalisme dalam spektrum yang berlawanan. Dalam sejarahnya, aliran ini selalu berupaya menentang semangat pluralisme, terlebih sekularisme, yang dalam konteks dunia modern, sedang mendera tata kehidupan umat muslim secara umum melalui perantara modernitas. Lihat, Richard C. Martin, Defenders of reason in Islam: Mu'tazilism from medieval school to modern symbol (Oxford: Oneworld Publications, 1997).

${ }^{5}$ Lihat, Fahrurrozi, Nilai-Nilai Ham Dalam Buku Ajar Pendidikan Agama Islam di Sekolah Menengah Atas (SMA) Daerah Istimewa Yogyakarta, (Jurnal Studi Agama Millah, Vol. IV, No. 2, Januari 2005) dalam, http://www.msi-uii. net/Pendidikan\%20dan\%20HAM.pdf (di akses 6 Juni 2009)
Rohis di sekolah-sekolah adalah adanya perkembangan paradigma sekolah yang pada awalnya lebih berupaya mengunggulkan mutu akademis, tetapi atas memenuhi tuntutan dan kebutuhan masyarakat yang menginginkan juga anak-anaknya berkembang potensi spiritualitasnya, maka sekolahsekolah berusaha menumbuhkan nuansa keberagamaan di lingkungan sekolahnya, yang salah satunya adalah memberikan dukungan terhadap aktifitas keagamaan pada Rohis. Inilah kiranya dari berbagai faktor tersebut dapat kita amati fenomena tumbuh berkembangnya aktifitas Kerohanian Islam (Rohis) di lingkungan sekolah-sekolah.

Artikel ini tidak dalam rangka mengangkat pengaruh guru pendidikan agama, baik pemahaman keagamaan maupun model pembelajaran yang dikembangkan guru dalam proses pembelajaran ataupun berkaitan dengan muatan kurikulum pendidikan agama yang diimplementasikan. Tetapi, artikel yang diangkat dari sebagian hasil penelitian ini mengungkapkan bagaimana sikap sosial keagamaan Rohis di SMA, yang berkaitan dengan tiga aspek, yaitu Islam dalam kehidupan sosial, Islam dalam kehidupan politik kenegaraan, dan Islam dalam kesetaraan jender.

Oleh karena itu, penelitian ini bertujuan diantaranya untuk mengetahui sikap sosial keagamaan Rohis SMA yang dilihat dari pemahaman aktivis Rohis berkaitan dengan Islam dalam kehidupan sosial, Islam dalam kehidupan politik kenegaraan, dan Islam dalam kesetaraan gender.

Metode yang digunakan dalam penelitian ini dirumuskan sesuai dengan kebutuhan jenis data yang akan digali. Data tentang sikap dan pandangan para aktivis Rohis, termasuk para pembina Rohis, dilakukan melalui wawancara mendalam (indepth interview) dengan sejumlah tokoh kunci yang terkait dengan gerak perkembangan Rohis di sekolah. Metode yang sama juga digunakan dalam konteks melacak persepsi sekaligus pandangan mereka terkait 
isu-isu sosial, politik, keagamaan, termasuk isu seputar kesetaraan jender yang tampaknya di Indonesia mulai tampak implementasinya. Selain menggunakan wawancara mendalam, penelitian ini juga melakukan observasi dan kajian literatur ataupun dokumentasi yang berkaitan dengan aktifitas keagamaan Rohis di SMA.

Pembahasan subjek penelitian ini lebih banyak didasarkan pada data-data yang diperoleh melalui wawancara dengan pihakpihak yang terlibat, baik langsung maupun tidak, dengan kehidupan keagamaan di sekolah, tepatnya Rohis. Untuk itu, sejumlah SMA dipilih di delapan (8) wilayah yang menjadi sasaran penelitian, DKI Jakarta, Kota Yogyakarta, Kota Semarang, Kota Bandung, Kota Medan, Kota Palangkaraya, Kota Manado, dan Kota Kupang.

Dalam pengumpulan data lapangan, penulis dibantu oleh peneliti dari Puslitbang Pendidikan Agama dan Keagamaan, serta peneliti dari UIN Jakarta. Penulis sebagai salah satu tim peneliti ditugaskan menulis bagian laporan hasil penelitian pada bab Sikap Sosial Keagamaan Rohis SMA. Pada laporan hasil penelitian utuhnya mencakup bab Rohis Sebagai Fenomena Keagamaan di SMA dilihat dari tinjauan historis, bab Jaringan Keagamaan dan Sumber Rujukan Keilmuan, dan bab mengenai Aktivitas Rohis, dan sebagainya.

\section{Kajian Pustaka}

Untuk memahami sikap sosial keagamaan Rohis di SMA pada dasarnya tidak lepas memahami bagaimana gerakan keagamaan sekitar Rohis itu sendiri. Gerakan keagamaan di sini dipahami dalam kerangka umum yang sering digunakan beberapa pengamat sosial yakni sebuah gerakan sosial yang berkaitan dengan isu-isu spiritual atau hal-hal yang gaib (supernatural), yang menentang atau mengusulkan alternatif terhadap beberapa aspek dari agama atau tatanan kultural yang dominan. ${ }^{6}$ Muncul dalam konteks lokal tertentu, gerakan keagamaan cendrung memosisikan satu spektrum pemikiran sebagai pelegitimasi pergerakan mereka secara umum. Terikait dengan hal ini, Diane Singerman, memaparkan bahwa model pergerakan komunitas ini dapat dengan mudah tercirikan melalui visi dan misi umum yang mereka jalani. Para anggota komunitas ini misalnya dengan keyakinan tinggi berupaya merancang agenda utama seputar persoalan-persoalan fundamental tentang makna hidup dan bagaimana praktik-praktik Islam hendaknya merasuki elemen keseharian kita mulai dari segi hukum, moralitas, ekonomi hingga politik pemerintahan. ${ }^{7}$ Lebih jauh, mereka juga misalnya, sangat menjaga esensi identitas kolektif yang memang dibentuk dari adanya keselarasan tujuan dasar mereka. Dan dari perasaan identitas kolektif yang kuat itulah, rasa solidaritas tercipta dengan mengambil beragam sarana informal-seperti kampus, sekolah, ataupun masjid-sebagai sarana pemerkuat pembentukan solidaritas tersebut. Lebih jauh, sarana-sarana itulah yang pada akhirnya menjaga jaringan diantara mereka tetap terajut baik sehingga hasilnya dapat memobilisasi para anggotanya dalam sebuah kesatuan gerakan. ${ }^{8}$

Dalam kerangka teori itulah, sikap sosial keagamaan Rohis di bangun. Kharakteristik umum seperti yang telah terjelaskan di atas

${ }^{6}$ Terkait definisi term tersebut lihat misalnya, Mayer N. Zald dan Robert Ash. "Social Movement Organizations Growth, Decay, and Change" (Social Forces 44, 1966) hlm.327-340 serta Mayer N. Zald dan John D. McCarthy (eds.). The Dynamics of Social Movement: Resource Mobilization, Social Control, and Tactics, (Cambridge, MA: Winthrop,1979).

7 Kerangka teori tentang gerakan keagamaan siswa ini kami sandarkan pada buku Aktivisme Islam, Pendekatan Teori Gerakan Sosial, (Paramadina, 2007). Buku ini merupakan edisi Indonesia dari buku karya Quintan Wiktorowicz (ed.), Islamic Activism: A Social Theory Approach, (Bloomington \& Indianapolis: Indiana University Press).

8 Lihat, Diane Singerman, Dunia Gerakan Sosial Islamis yang Berjejaring, dalam Quintan Wiktorowicz (ed.), Aktivisme Islam, Pendekatan Teori Gerakan Sosial, (Jakarta: Paramadina, 2007), 191-195. 
pada gilirannya menjadi catatan tersendiri tatkala kita mengamati pergerakan kerohanian Islam (Rohis) yang nyatanya, memiliki banyak kemiripan agenda. Jika diatas, term yang digunakan adalah gerakan keagamaanbersifat global-maka selanjutnya, kita akan masukan kerangka tersebut dalam entitas yang lebih spesifik, sebuah term khusus yang dalam konteks ini kita namai, gerakan keagamaan siswa. Gerakan keagamaan siswa jelas berangkat dari sebuah pandangan bahwa sebuah pergerakan tak hanya merujuk pada satu entitas besar, namun lebih jauh, dapat pula mengacu pada satu entitas kecil yang terdapat di sebuah wilayah, tak terkecuali lembaga sekolah. Dalam konteks ini kehadiran Rohis pada sekitar awal tahun 80-an, memang memberi kecenderungan baru bagi arah pergerakan aktivisme Islam di kalangan peserta didik. Lembaga pendidikan, sekolah, akhirnya menjadi sarana efektif bagi sebuah proses sosialisasi paham keagamaan dan bersamaan dengan itu menjadi media diseminasi ideologi Islam tertentu. Ideologi yang dimaksud adalah sebagaimana yang dibawa oleh kaum yang meyakini kekuatan gerakan revivalisme Islam. Lebih jauh, dari sanalah, Rohis telah benar-benar merubah orientasi gerakannya, dari sebuah bagian kecil dari sistem sekolah, menjadi sebuah entitas yang lebih besar, sebuah gerakan keagamaan siswa, yang pada akhirnya mengkristal menjadi sikap sosial keagamaan Rohis di SMA.

\section{Operasionalisasi Sikap Sosial Keagamaan}

Islam dalam kehidupan sosial. Kehidupan sosial dalam tulisan ini dimaksudkan sebagai sebuah bentuk relasi kehidupan antarindividual (antar-personal), antar-golongan ataupun antar-komunitas yang bernaung dalam sebuah kesatuan, masyarakat Di dalamnya, tercakup beberapa rumusan sikap yang akan turut mengiringi laju kehidupan bersama tersebut, diantaranya civic value, multikulturalisme, dan toleransi. Jika toleransi sederhananya dipahami sebagai sebuah sikap individu, bisa juga kelompok, yang muncul ketika seseorang ataupun kelompok tersebut berhadapan dengan sejumlah perbedaan dan bahkan pertentangan di tengah masyarakat, maka multikulturalisme lebih jauh dipahami sebagai sebuah bentuk kerelaan diantara para komunitas tersebut untuk hidup dalam kerangka kemajemukan, baik dalam ranah etnis, agama, ataupun budaya, dalam suatu negara.

Dalam tulisan ini, keduanya digunakan untuk mengetahui, sejauh mana sikap anggota Rohis dalam kehidupan sosial, utamanya sikap toleransi, yang mereka jalani di tengah masyarakat. Untuk memudahkannya, beberapa variebel yang selanjutnya dijadikan ukuran memperoleh gambaran utuh tentang sikap ini diungkap melalui serangkaian pertanyaan yang ditujukan baik kepada anggota maupun pembina Rohis di beberapa sekolah. Dari sanalah kemudian didapatkan pernyataan ataupun komentar yang pada gilirannya menjadi penjelas atas gambaran sikap para responden.

Beberapa variabel pertanyaan yang mengemuka diantaranya, apakah sebaiknya anggota Rohis berteman dekat dengan orangorang yang beragama Islam saja, bahwa orangorang non Islam tidak akan senang dengan orang Islam sebelum orang-orang islam ikut agamanya, dan hanya Islam yang benar dan karena itu non-Islam harus masuk agama Islam. Selanjutnya, apakah keberatan bertetangga dengan orang yang berbeda agama? Jika ya, mengapa? atau keberatankah bila yang berbeda agama itu mengadakan acara kebaktian di lingkungan sekitar, keberatankah jika mereka yang berbeda agama itu memberi bantuan ke lembaga-lembaga Islam (pesantren, madrasah, mesjid, dsb) atau sebaliknya jika orang Muslim membantu lembaga-lembaga non-Islam (gereja, pura, vihara, kelenteng, kuil).

Termasuk dalam hal cakupan variabel ini adalah apakah diperbolehkan guru-guru nonMuslim mengajar di sekolah Islam, madrasah 
atau pesantren, begitu juga sebaliknya, bagi guru Muslim yang mengajar di sekolah nonIslam. Kemudian, bagaimana pandangan mereka jika ada dalam keluarga (seperti anak, adik, kakak atau saudara dekat lain) dari mereka yang menikah dengan orang yang berbeda suku atau ras, terlebih berbeda agama? Dan bagaimana sikap terhadap aktivitas memberikan ucapan selamat (seperti Selamat Natal atau Selamat Waisak) kepada orang yang beragama lain, atau terhadap tindakan sekelompok orang yang menutup atau merusak rumah ibadah kelompok lain, bahkan lebih jauh, menyerang kelompok agama lain (seperti kasus Ahmadiyah).

Islam dalam kehidupan politik kenegaraan. Kehidupan politik kenegaraan dalam bagian ini difokuskan pada beberapa isu utama yang mencakup diantaranya: relasi agama dan negara, evaluasi atas sistem demokrasi, dan realisasi sistem khilafah Islamiyah di Indonesia. Terkait beberapa fokus isu tersebut, beberapa variabel yang digunakan untuk mengukur sikap dan pandangan siswa mengenai hal ini terumuskan dalam bentuk pernyataan dan pertanyaan sebagai berikut; sejauhmana posisi agama dalam proses kehidupan bernegara di Indonesia dan bagaimana hubungan yang ideal keduanya; sejauhmana negara boleh mencampuri urusan kehidupan beragama, bagaimana pandangan tentang partai-partai Islam dalam pemilu, apakah pemerintah harus tetap mempertimbangkan pandangan agama dalam pengambilan semua keputusan yang menyangkut kehidupan masyarakat.

Selain itu, dikarenakan bangsa Indonesia adalah bangsa yang beragama, maka bagaimana kehidupan keagamaan seharusnya diatur, dan apakah aturan-aturan yang dibuat dan dijalankan negara harus sesuai dengan semangat Islam atau jika tidak sesuai, maka bagaimana prospek aturanaturan itu dikemudian hari, harus ditolak atau sebaliknya, didukung, apakah pemimpin negara harus beragama Islam, apakah setiap agama yang ada di dunia dewasa ini berhak hidup dan berkembang di tanah air tanpa syarat dan memiliki hak yang sama dengan agama mayoritas di tanah air, dan apakah Kementerian Agama berhak melarang berkembangnya ajaran agama yang dianggap menyimpang.

Masih terkait dengan pertanyaan terakhir, apakah pemerintah mampu menjalankan fungsinya mengatur administrasi kehidupan beragama di tanah air, apakah demokrasi itu sesuai dengan prinsip-prinsip agama Islam, bagaimana pandangan tentang demokrasi di Indonesia, apakah lembaga-lembaga negara menjalankan fungsinya sesuai dengan semangat demokrasi, dan sebagai proses evaluasi diri, bagaimana pendapat responden tentang sistem demokrasi, masihkan harus dipertahankan atu sebaliknya, kita beralih ke bentuk sistem pemerintah Islam, terkait dengan ini, maka bagaimana kemungkinan diberlakukannya syariat Islam.

Islam dalam kesetaraan jender. Keluarga yang baik adalah keluarga yang memberikan peran kepada seluruh anggota keluarga secara seimbang. Baik laki-laki dan perempuan mendapat akses yang sama dalam segala bidang. Melihat hasil perbincangan dengan para aktivis Rohis di berbagai daerah, terlihat bahwa umumnya, mereka berpendapat, peran perampuan dalam rumah tangga di ruang publik haruslah mengikuti kesepakatan yang dibentuk dalam rumah tangga dengan syarat semua ketentuan itu atas izin pihak suami.

\section{HASIL DAN PEMBAHASAN}

\section{Islam dalam Kehidupan Sosial}

Penelitian ini menemukan fakta bahwa dalam konteks kehidupan sosial, para aktivis Rohis SMA bersikap terbuka. Mereka bersedia menjalin hubungan sosial (diistilahkan dengan kata gaul) dengan pihak manapun, asalkan berada dalam kerangka Islami. Sebatas bahwa jalinan tersebut tetap menggunakan Islam sebagai landasannya dengan tidak sampai 
pada adanya pengupayaan pemisahan antara kehidupan duniawi dan ukhrawi. Artinya, jalinan hubungan sosial yang dibangun tidak boleh melanggar ketentuan-ketentuan yang dilarang dalam ajaran Islam. Dengan berpegang pada konsep tersebut, para aktivis Rohis cenderung menerima fakta adanya kemajemukan di masyarakat. Kemajemukan merupakan sesuatu yang semestinya diterima apa adanya, itulah yang misalnya diungkapkan oleh Juan Arifianto, seksi perelangkapan rohis SMAN 4 Semarang. Dengantegas ia menyatakan perbedaan yang terjadi di masyarakat tidak perlu dipermasalahkan karena memang manusia diciptakan secara berbeda-beda. ${ }^{9}$

Dengan nada mendukung pandangan tersebut, Rahimin, Pembina Rohis SMAN 4 Palangkaraya, memaparkan secara tegas bahwa kemajemukan dalam kehidupan bermasyarakat di Indonesia merupakan sesuatu yang tidak dapat dipungkiri dan menjadi kekayaan yang dimiliki oleh bangsa Indonesia. Dengan penguatan atas kehidupan majemuk itulah, terjadinya riak-riak konflik akan mereda seiring berkembangnya sikapsikap arif dan bijaksana dari seluruh elemen masyarakat. ${ }^{10}$

Masih terkait dengan hal ini, Srimyati, Pembina Rohis SMAN 1 Bandung, memaparkan bahwa bagi orang yang sudah memiliki dasar, keragaman organisasi agama seperti $\mathrm{NU}$, Muhamadiyah, Persis, dan beberapa organisasi lain, tidaklah menjadi masalah. Baginya, mereka yang sudah mengerti kemajemukan tersebut di dalam dirinya tidak akan terjadi perselisihan. Yang jadi masalah adalah bagi mereka yang awam, yang baru aktif belakangan ini. Karena jika terjadi perbedaan pendapat, terkadang mereka saling memojokkan. Hal itu karena mereka tidak punya dasar kuat. Sebagai contoh, ketika menghadapi masalah khilafiyah, maka sebenarnya itu tidak perlu terjadi, jika

${ }^{9}$ Wawancara dengan Juan Arifianto, Anggota Rohis SMAN 4 Semarang

${ }_{10}$ Wawancara dengan Rahimin, Pembina Rohis SMAN 4 Palangkaraya. saja kita memahami bahwa perbedaan adalah rahmat. ${ }^{11}$

Dengan demikian jelas bahwa mayoritas perangkatRohis baikanggota maupunPembina, memiliki kesamaan visi perihal kemajemukan. Adapun bentuk nyata dari sikap penerimaan atas kemajemukan tersebut dapat diamati misalnya dari sikap seseorang dalam memilih teman dekat. Hampir dalam setiap wawancara yang dilakukan dalam penelitian ini, sebagian besar responden menjawab tidak setuju jika mereka hanya berteman dengan umat muslim saja. Ali, pembina rohis SMAN 11 Yogyakarta misalnya berpandangan bahwa pergaulan dengan sesama muslim saja justru akan membatasi dan mempersempit pandangan umat Islam terhadap masyarakatnya sendiri, dan pada gilirannya, justru akan memperkeruh hubungan antar agama di Indonesia yang masih sangat rentan dengan konflik. ${ }^{12}$

Hal senada ditambahkan oleh Budi Basuki, Pembina Rohis SMAN Semarang, yang menyatakan bahwa tidak pantas seorang muslim bergaul hanya dengan sesama muslim saja. Karena manusia hidup bermasyarakat, maka seorang muslim harus bersosialisasi dengan masyarakat lain tanpa memadang agama. ${ }^{13}$ Pandangan seperti ini persis seperti yang diungkapkan oleh Salahudin Dja'far, wakil ketua rohis SMAN 4 Menado. Menurutnya, sebagai majkhuk sosial, kita pun harus berteman pula dengan non muslim. ${ }^{14}$

Begitupun dengan Srimyati, Pembina Rohis SMAN 1 Bandung. Menurutnya, sudah jelas kalau dalam masalah akidah kita harus menjaganya sendiri. Tapi dalam hal hubungan sesama manusia al-Quran sudah mengajarkan kita untuk berbuat baik. Bukan berarti kita mengikuti ibadahnya, tapi seperti

\footnotetext{
${ }^{11}$ Wawancara dengan Srimyati, Pembina IKARIS/ Rohis SMAN 1 Bandung

${ }^{12}$ Wawancara dengan Ali, Pembina Rohis SMAN 11 Yogyakarta.

${ }^{13}$ Wawancara dengan Budi Basuki, Pembina Rohis SMAN 4 Yogyakarta

${ }^{14}$ Wawancara dengan Shalahuddin Dja'far, anggota Rohis SMAN Menado.
} 
yang dilakukan Rasulullah tetap berakidah kuat sembari berteman untuk mengajak mereka dengan ramah. Jadi terpenting manurutnya, harus ada toleransi, karena alQuran menjelaskan bahwa kita tidak bisa memaksakan agama kepada orang lain. Dan karenanya jelas, sebagai makhluk sosial kita akan saling membutuhkan. ${ }^{15}$

Dengan nada sama, Aldila Dyas Nurfitri, anggota seksi dakwah Rohis SMAN 3 Semarang, menjelaskan, sudah seharusnya kita mencari teman sebanyak-banyaknya. Jangan membedakan dari agamanya. Menurutnya, yang terpenting hanyalah bahwa kita harus membatasi diri dalam konteks tertentu. ${ }^{16}$

Bentuk lain dari sikap penerimaan terhadap kemajemukan dalam bermasyarakat adalah dalam kehidupan bertentangga dengan yang berbeda agama. Sebagian besar responden yang diwawancarai dengan tegas menyatakan bahwa tak ada masalah ketika mereka harus hidup bertetangga dengan non muslim selama pihak non muslim tersebut tidak menggangu atau mempengaruhi kita untuk masuk agama mereka. Pendapat seperti itu misalnya disampaikan Makruf, ketua Rohis SMAN 29 Jakarta. Bahkan tak menjadi masalah jika nonmuslim mendirikan tempat ibadah di wilayah kita, karena itulah wujud penghormatan atas hak mereka dalam beragama. ${ }^{17}$ Senada dengan Makruf, Anwari, guru Pendidikan Agama Islam yang juga pembina Rohis SMAN 3 Semarang, berpendapat yang sama. Menurutnya, selama tidak mengganggu, seperti menggunakan alat musik dengan suara yang cukup keras, tak masalah baginya untuk bertetangga dengan non muslim ataupun jika pihak non muslim tersebut melaksanakanan ibadah disekitar rumahnya. ${ }^{18}$

${ }^{15}$ Wawancara dengan Srimyati, Pembina IKARIS/ Rohis SMAN 1 Bandung

${ }^{16}$ Wawancara dengan Aldila D. Nurfitri, anggota Rohis SMAN 3 Semarang. Jakarta

${ }^{17}$ Wawancara dengan Makruf, Ketua Rohis SMAN 29

${ }^{18}$ Wawancara dengan Anwari, Pembina Rohis SMAN 3 Semarang
Pandangan yang sama juga dikemukakan oleh Budi Basuki, Pembina Rohis SMAN 4 Yogyakarta. "Saya tidak keberatan bila yang berbeda agama itu mengadakan acara kebaktian di lingkungan saya, karena kita harus menghormati hak dan kewajiban seorang umat beragama". ${ }^{19}$ Begitu juga dengan Makruf, Ketua Rohis SMAN 29, dia menegaskan, boleh saja tetangga non-muslim melakukan ritual/peribadatan agamanya, karena itu merupakan hak dalam beragama. Asalkan tidak mengajak orangorang setempat mengikuti agamanya.

Meskidemikian, dari wawancarayang telah dijalani, terlihat bahwa secara umum, aktivis Rohis yang ditemui rata-rata membolehkan non-muslim menyelenggarakan kebaktian ataupun peribadatan di sekitar rumahnya, sejauh tidak menggangu lingkungan sekitar, terkhusus mengusik kehidupan mereka. Dengan mengacu pada keyakinan bahwa setiap warga memiliki hak untuk menjalankan kehidupan keberagamaan, maka menjaga pola multikultural di antara sesama warga masyarakat menjadi point penting yang selanjutnya mereka jadikan acuan ketika hidup bermasyarakat. Spirit yang sama, nampak ketika perbincangan diarahkan kepada respon mereka ketika melihat warga nonmuslim mendirikan tempat ibadah. Sebagai wujud pelaksanaan hak beragama, sebagian besar membolehkan umat lain mendirikan tempat ibadah sejauh memiliki izin dari pihak berwenang dan mendapat persetujuan dari warga setempat serta memiliki komitmen untuk tidak mempengaruhi warga setempat masuk agamanya.

Dari beberapa hasil wawancara seperti terjelaskan diatas, terlihat bahwa secara umum, para responden mampu bersikap terbuka dan toleran terhadap kelompok agama lain, baik dalam kehidupan bertetangga, beribadah, ataupun dalam menerima fakta kemajemukan dalam wilayah kepemimpinan. Data yang diperoleh juga menyebutkan

${ }^{19}$ Wawancara dengan Budi Basuki, Pembina Rohis SMAN 4 Yogyakarta 
bahwa baik aktivis maupun pembina Rohis, cenderung tak berkeberatan terhadap non muslim yang menjadi tenaga pengajar di sekolah umum. Hanya saja, itu terbatas pada mata pelajaran umum, sedangkan untuk mata pelajaran agama, tetap bahwa mereka masih belum bisa menerima jika non muslim mengajar pendidikan agama. Pendapat positif juga disampaikan Anwari, pembina Rohis SMAN 3 Semarang. Menurutnya, justru dengan adanya guru non muslim yang mengajar di sekolah muslim itulah pada gilirannya akan semakin menambah keluwesan bagi para guru dan murid dalam pergaulan bermasyarakat. ${ }^{20}$ Namun, untuk konteks sekolah Islam, banyak pihak yang masih keras berkeyakinan bahwa guru non-muslim tidak seharusnya mengajar di sekolah Islam, seperti madrasah. Pandangan ini misalnya dipaparkan oleh Budi Basuki. Dalam kapasitasnya sebagai guru agama dan pembina Rohis SMAN 4 Yogyakarta, dengan tegas ia melarang guru non muslim mengajar di sekolah muslim karena menurutnya, dapat mengganggu kenyamanan masing-masing pihak dalam menjalankan tugasnya. ${ }^{21}$ Rahimin di SMAN 4 Palangkaraya mendukung pendapat ini, menurutnya tidak pantas guru non muslim mengajar di sekolah Islam, begitu juga sebaliknya guru muslim tidak diperbolehkan mengajar di sekolah non-muslim, karena tidak sesuai dengan visi dan misi sekolah Islam. ${ }^{22}$

Dari beberapa pendapat di atas, dapat digariskan bahwa sebagian responden memperbolehkan guru non muslim mengajar di sekolah umum asalkan yang diajarkan adalah mata pelajaran umum. Namun demikian, beberapa responden merasa khawatir jika non muslim tersebut mengajar di pesantren atau madrasah karena khwatir akan mempercampurkan keyakinan agama mereka.

\footnotetext{
${ }^{20}$ Wawancari dengan Anwari, Pembina Rohis SMAN 3 Semarang

${ }^{21}$ Wawancara dengan Budi Basuki, Pembina Rohis SMAN 4 Yogyakarta

${ }^{22}$ Wawancara dengan Rahimin, Pembina Rohis SMAN 4 Palangkaraya
}

Selanjutnya, berkaitan dengan sikap penerimaaan sumbangan atau bantuan dalam bentuk uang atau barang dari lembaga non muslim kepada kaum muslim, seluruh aktivis dan pembina Rohis, merasa tidak keberatan bila bantuan tersebut diberikan secara tulus dan ikhlas demi kemanusiaan, bukan untuk maksud-maksud misionaris tertentu. Muhammad Alim, pembina Rohis SMUN 4 Menado misalnya menyatakan bahwa ia merasa tidak keberatan jika non muslim memberikan bantuan atau sumbangan ke lembaga muslim atau sebaliknya. ${ }^{23}$

Sementara itu, terkait pandangan mengenai pernikahan beda ras, suku, dan latar belakang budaya, hampir seluruh responden yang telah diwawancarai memiliki persamaan pandangan. Secara umum responden menjawab merasa tidak keberatan laki-laki atau perempuan muslim menikah berbeda suku, ras, dan latar belakang budaya. Namun, hal ini berbeda dengan pandangan responden mengenai pernikahan beda agama. Secara umum para responden menyarankan jika bisa dihindari sebaiknya jangan sampai terjadi pernikahan beda agama.

Terkait dengan sikap dan keyakinan bahwa Islamlah satu-satunya agama yang membawa kebenaran dan yang paling memberikan jaminan keselamatan kepada umat Islam, maka dalam rangkaian wawancara yang telah dilakukan mulai dari Medan, Jakarta, Bandung, Kupang, Palangkaraya, Menado, dan beberapa daerah lainnya, terdapat kecenderungan bahwa sebagian besar responden sangat menyetujui dan menyepakatinya. Namun demikian, tidak setuju pula jika mereka harus memaksakan Islam yang benar itu kepada orang-orang non muslim. Terlebih memaksakan kehendak kita agar mereka masuk Islam. Menurut mereka, memaksakanan kehendak, terlebih keyakinan agama, kepada orang lain, merupakan perbuatan yang tidak terpuji. Selaras dengan pandangan tersebut, Ali, pembina pada Rohis

${ }^{23}$ Wawancara dengan Muhammad Alim, Pembina Rohis SMAN 4 Menado 
SMAN 11 di Yogyakarta menambahkan bahwa sejatinya ia setuju jika hanya Islam yang benar. Namun jika non muslim dipaksakan untuk masuk Islam, ia sangat menolak hal tersebut."Saya tidak setuju, karena memaksakan kehendak kepada orang lain sesungguhnya perbutaan yang melampui batas, dan Tuhan tidak menyukai orang-orang yang berbuat demikian, dan di dalam al-Qur'an disebutkan bahwa untukmu agamamu dan untukku agamaku. Jelas, tidak ada paksaan di dalamnya." ${ }^{24}$ Pandangan tersebut terlihat sangat prinsipil bagi para responden. Dan ini disebabkan karena dalam faktanya, ini sudah masuk ke dalam wilayah pembahasan akidah.

\section{Islam dalam Kehidupan Politik Kenegaraan}

Dari penelitian ini, terkait posisi agama dalam proses kehidupan berbangsa dan bernegara di Indonesia serta hubungan yang ideal di atara keduanya, hampir seluruh responden (aktivis dan pembina Rohis) menginginkan Islam menjadi landasan dalam bersikap dan berperilaku bagi bangsa dan negara. Pandangan seperti itulah yang banyak diyakini oleh para anggota Rohis, seperti misalnya Abdilah Azis, Ketua Rohis SMAN 3 Semarang. Menurutnya, Indonesia sudah semestinya untuk hidup dengan berlandaskan pada kerangka agama, dan Islam, sudah memberikan semua tuntunan dan aturan yang sempurna mengenai tata cara pemerintahan tersebut. $^{25}$ Idealnya, kaidah-kaidah pemerintahan, termasuk sumber aturan dan kebijakannya, memang harus menggunakan dasar-dasar agama yang ada dalam al-Qur'an dan al-Sunnah. Dengan kata lain, negara harus mampu mengatur kehidupan umat beragama, terutama dalam masalah muamalah. ${ }^{26} \mathrm{Se}-$

${ }^{24}$ Wawancara dengan Ali, Pembina Rohis SMAN 11 Yogyakarta

${ }^{25}$ Wawancara dengan Abdilah Azis, Ketua Rohis SMAN 3 Semarang

${ }^{26}$ Wawancara dengan Muhammad Alim, Pembina Rohis SMAN 4 Manado buah idealiasasi yang alhasil juga turut diyakini oleh para guru agama dan anggota Rohis di SMAN 4 dan SMAN 11 Yogyakarta. Dengan tegas mereka, seperti halnya dengan responden di Kupang, meyakini bahwa Islam mampu menjadi pedoman dalam membentuk perilaku masyarakat, dan karenanyalah, relasi agama dan negara harus selalu terjalin erat demi terciptanya negara yang ideal. ${ }^{27}$ Sedangkan tentang evaluasi atau penilaian terhadap sistem demokrasi yang diterapkan di Indonesia, meskipun pemahaman para aktivis tentang makna demokrasi, dari rakyat, untuk rakyat dan oleh rakyat, cukup baik, namun mereka berkeyakinan bahwa makna demokrasi tersebut tidak sepenuhnya diterapkan oleh berbagai negara demokrasi, termasuk Indonesia. Dengan nada yang sama, seorang aktivis Rohis asal Jakarta berpendapat, "Menurut saya boleh-boleh saja sistem demokrasi diterapkan tetapi selama ini sistem demokrasi banyak menyimpang dari ajaran Islam". ${ }^{28}$

Pun demikian pandangan yang diberikan Rosyikhuna FA, Ketua Rohis SMAN 70 Jakarta. Menurutnya, bentuk demokrasi di Indonesia sangat tidak jelas keberadaannya. Terkadang bercorak liberal, tapi seringkali juga berkarakter, sosialis. Karenanya terlihat bahwa demokrasi belum mampu menjadi sistem yang konsisten. Dan karena sistem demokrasi tersebut masih bermasalah, maka sistem pemerintahan Islam, khilafah islamiyah, alhasil menjadi alternatif terbaik atas sistem demokrasi tersebut. Karena jelas, Islam pun telah mencakup definisi demokrasi seperti membela kepentingan rakyat, rasa saling membantu, bermusyawarah, dan beberapa prinsip demokrasi lainnya. ${ }^{29}$

Adapun, untuk merealisasikan idealisasi tersebut, maka sebagian besar anggota Rohis

${ }^{27}$ Wawancara dengan Ali dan Budi Basuki di SMAN 4 dan 11 Yogyakarta Jakarta

${ }^{28}$ Wawancara dengan Makruf, Ketua Rohis SMAN 29

${ }^{29}$ Wawancara dengan R. Fikri Asyafari, Ketua Rohis SMAN 70 Jakarta 
berkeyakinan, penting bagi segenap umat muslim, mendukung wakil-wakil rakyat berlatar belakang keagamaan kuat, duduk di jajaran pemerintahan, legislatif. Sehingga dari merekalah perjuangan menegakkan nilai-nilai Islam dalam bermasyarakat dan bernegara akan benar-benar terwujud.

Tentang hal ini, Makruf berpendapat, wajib hukumnya memilih caleg dari muslim, karena sejatinya, mereka yang akan mengurus pemerintahan ini haruslah paham akan aturan-aturan Islam. Dan para wakil rakyat yang mengerti hukum agama akan meyakini bahwa kehendak agama sesungguhnya adalah juga kehendak rakyat keseluruhan. Karenanya, mereka akan sungguh-sungguh menjalankan tanggung jawabnya sebagai seorang muslim dan sebagai seorang negarawan. Terlebih, ada prinsip utama yang diyakini oleh mereka bahwa berbuat sesuatu yang tidak sesuai dengan agama, resikonya akan masuk neraka. Maka, itulah pentingnya kita memilih orang muslim sebagai pemimpin pemerintahan. ${ }^{30}$ Lebih jauh, mereka berasumsi bahwa agama yang diturunkan oleh Tuhan sesungguhnya berfungsi untuk memudahkan usaha manusia, maka jika sistem Islam ditegakkan niscaya akan memudahkan rakyatnya. Lagi pula, agama Islam juga bersifat mengatur seluruh aspek kehidupan manusia dan aturan itu tertuang dalam al-Qur'an dan hadits Nabi. Maka dari itu, sudah saatnya agama menjadi sumber aturan untuk mengatur negara. Terkait hal ini, anggota rohis SMAN 29 berpendapat, "semua bidang kehidupan sudah ada dalam alQur'an, manusia tidak perlu merepotkan diri membuat undang-undang karena semuanya sudah diatur dalam agama. Pendapat sedikit berbeda disampaikan salah seorang pengurus Rohis SMAN 70 Jakarta, meskipun negara Indonesia menganut sistem demokrasi, bangsa ini masih memiliki ulil amri, pemimpinpemimpin agama sebagai penjaga syariat dan keutuhan umat Islam. Sejauh kebijakanJakarta

${ }^{30}$ Wawancara dengan Makruf, Ketua Rohis SMAN 29 kebijakan yang dikeluarkan oleh sistem negara demokrasi tidak keluar dari koridor syariat dan masih mendapat perseutujuan dari ulil amri maka umat Islam harus mematuhinya "samina wa ata'na". Jika perbuatan negara tersebut sudah betul-betul jauh menyimpang dari ketentuan agama maka umat Islam harus mencegahnya sedapat mungkin. ${ }^{31}$ Namun yang jelas, setiap usaha untuk menegakkan nilai-nilai Islam dalam masyarakat dan negara sejauh mengacu kepada sumber-sumber Islam yang otentik layak untuk didukung. Meskipun demikian, tidak semua kelompok yang berjuang menegakkan syariat Islam dapat didukung, banyak juga kelompok-kelompok mengatasnamakan Islam tetapi tidak sesuai dengan nilai-nilai Islam.

Maka dari sana jelas, bahwa menyangkut sistem Islami, para aktivis meyakini bahwa sistem pemerintahan Islami merupakan yang terbaik. Meskipun sudah banyak sistem pemerintahan yang diterapkan di muka bumi dengan berbagai ideologi yang mendukugnya, sistem pemerintahan Islami tetap menjadi pilihan terbaik. Para aktivis meyakini bahwa Islam telah menjadi idola di berbagai negara di berbagai belahan dunia karena menjamin keragaman masyarakat. Dengan mengacu pada beberapa kasus seperti Malaysia, yang dalam pandangan para anggota Rohis, mampu merealisasikan gagasan ideal tersebut, maka pada gilirannya, sistem khilafah inilah yang akan mendapat banyak simpati dari bangsa lain. $^{32}$

Bentuksimpatidaribangsa lainitumenurut mereka, dapat dilihat misalnya pada kondisi dimana bank syariah, atau secara umum, ekonomi syariah, akan dijadikan referensi penting bagi sebuah pola perekonomian Islam global. Menurut para aktivis Rohis tersebut, untuk saat ini memang peran negara dalam memperhatikan umat masih kurang, dan

${ }^{31}$ Wawancara dengan R. Fikri Asyafari, Ketua Rohis SMAN 70 Jakarta Jakarta

\footnotetext{
${ }^{32}$ Wawancara dengan Makruf, Ketua Rohis SMAN 29
} 
itu terutama pada kurangnya penekanan kepada perealisasian syariat Islam. Inilah yang dalam pandangan mereka sebab mengapa kemiskinan masih mendominasi kehidupan bangsa Indonesia.

\section{Islam dalam Kesetaraan Jender}

Makruf, dari SMAN 29 menyatakan "Jika suami mengizinkan istrimencari nafkah kenapa tidak asalkan mendapat izin dari suami". Lakilaki boleh berpoligami dengan syarat harus mendapatkan izin dari istri pertama, "Jika keduanya sudah setuju boleh melakukan poligami". Akan tetapi responden merasa keberatan jika peristiwa ini terjadi pada kedua orang tua mereka. Bapak boleh kawin lagi jika si istri meninggal dunia, karena Rasululullah menikah lagi setelah istri pertamanya meninggal. "Rasulullah melakukan poligami setelah istrinya meninggal". ${ }^{33}$

Para aktivis berbeda pandangan menyikapi fenomena poligami oleh para ulama. Menurut mereka tindakan seorang ulama melakukan poligami berdasarkan kepada perintah agama. "Justru karena mengatahui perintah agama itulah ulama melakukan poligami", ujar salah seorang peserta diskusi. Mereka berpoligami untuk mendapatkan ridho Allah dan Rasulnya. Kalaupun banyak nada miring kepada Aa gym karena media massa ikut serta menciptakan opini tidak sehat terhadap kasusnya, padahal keluarga Aa Gym menyikapinya wajar-wajar saja. Pandangan berbeda disampaikan oleh salah seorang aktivis. Popularitas Aa Gym merosot drastis di mata masyarakat khsususnya kaum perempuan pasca berpoligami dengan salah seorang jamaahnya. Ini sebagai bukti bahwa masyarakat tidak menyetujui poligami. "Pamor AA gym semakin berkurang di mata ibu-ibu, karena para ibu tidak setuju dengan poligami sehingga orang yang poligami tidak bisa dijadikan contoh. ${ }^{34}$ Rohis

${ }^{33}$ Wawancara dengan Makruf, Ketua dan pengurus ${ }^{34}$ Wawancara dengan Vini, Mulyani, dan Adriyani
Dalam bidang pendidikan anak lakilaki mendapat peluang lebih besar dari perempuan, mereka berasumsi bila anak lakilaki disekolahkan terlebih dahulu nantinya akan mengajarkan si perempuan, anak lakilaki juga dapat membantu ekonomi keluarga. "Kalau bisa anak laki-laki lebih didahulukan, jika anak laki-laki disekolahkan si perempuan bisa belajar dari laki-lakinya, jika anak laki-laki bekerja manfaatnya bisa membantu keluarga" ungkap salah seorang aktivis SMAN 29 di Jakarta. Pandangan yang sama diberikan oleh R. Fikri dari SMAN 70 Jakarta. Menurutnya, memang sebaiknya anak laki-laki terlebih dahulu disekolahkan ketimbang perempuan, karena secara psikologis perempuan lebih dominan perasaan ketimbang laki-laki yang dominan pikiran. Dari perspektif agama lakilaki merupakan tulang punggung perempuan, untuk mencari nafkah, bekerja, dan lain-lain. ${ }^{35}$

Karenanya, terkait perda tentang perempuan, baik Makruf ataupun Fikri lebih melihat bahwa seyogyanyalah perempuan tidak bepergian di malam hari, dan jikapun terpaksa harus pergi, maka wajib baginya ditemani. Logika bahwa kejahatan ada di manamana, menyebabkan dalam banyak hal mereka sangat menyetujui jika pemerintah daerah membuat Perda terkait hal-hal tersebut. Karena inisiatif Pemerintah daerah membuat Perda pasti dilandasi oleh tujuan positif yang akan berguna bagi warganya dikemudian hari. Alhasil, jika respon dari masyarakat positif dan manfaatnya diharapkan oleh masyarakat luas, maka sejatinya, Perda tersebut memang perlu diperbanyak dan benar-harus dimaksimalkan penerapannya.

Terkait masalah kepemimpinan, beberapa responden yang diwawancarai menyatakan bahwa sebagaimana anjuran para ahli figh, terkhusus perihal ketentuan imam dalam shalat berjamaah, maka sesuai surat alNisa ayat 34 , dalam konteks kepemimpinan, diperlukan suatu keteguhan untuk menjadi

${ }^{35}$ Wawancara dengan R. Fikri Asyafari, Ketua Rohis SMAN 70 Jakarta 
seorang imam. Dan selagi masih ada laki-laki maka seharusnya laki-laki yang harusnya menjadi memimpin, apalagi menjadi presiden.

Itulah mengapa, Budi Basuki, Guru Agama Islam SMAN 4 Yogyakarta, menegaskan ketidaksetujuannya pada presiden perempuan. Menurutnya, karena posisi presiden berkaitan dengan pengambilan keputusan penting dan sekaligus menjalankan amanah besar, maka keputusan yang baik seharusnya tidak disetai dengan perasaan, dan ini yang ditakutkan ketika presidennya adalah seorang perempuan. Sebagai contohnya, hal itu dapat dilihat pada kasus yang dialami oleh mantan presiden Megawati ketika bermasalah dengan Susilo Bambang Yudhoyono yang kala itu masih menjadi menteri pada kabinetnya.

Dari beberapa penjelasan di atas, setidaknya kita mengambil pemahaman bahwa pandangan serta sikap para aktivitas Rohis terkait isu-isu gender masih belum beranjak dari temuan yang dulu pernah diungkap, yaitu adanya kecenderungan eksklusif pada sebagian anggota Rohis, pun penelitian ini yang tampaknya juga menemukan kecenderungan yang sama. Para aktivis Rohis masih cenderung menempatkan perempuan-baik di lingkup domestik maupun publik - dalam posisi yang subordinat. Seraya mengafirmasi poligami sebagai sebuah realisasi ajaran syari'at Islam mereka juga terlihat memposisikan jilbab sebagai atribut wajib bagi perempuan. Selain itu, mereka juga tampak mementingkan posisi laki-laki baik dalam keluarga ataupun secara luas, dalam dunia politik kenegaraan.

\section{PENUTUP}

\section{Kesimpulan}

Dalam kaitannya dengan isu-isu jender, aktivis Rohis masih cenderung menempatkan perempuan-baik di lingkup domestik maupun publik-dalam posisi yang subordinat dari lakilaki. Seraya mengafirmasi poligami sebagai sebuah realisasi ajaran syari'at Islam mereka juga terlihat memposisikan jilbab sebagai atribut wajib bagi perempuan. Selain itu, mereka juga tampak mementingkan posisi lakilaki baik dalam keluarga ataupun secara luas, dalam dunia politik kenegaraan. Yang mungkin perlu digaris bawahi dari penelitian ini adalah meskipun di satu aspek, semisal jender, sikap dan pandangan mereka cenderung seragam, namun pada aspek lainnya, hal itu terkadang berbeda. Hal itu ditemukan misalnya pada ragam sikap dan pandangan mereka dalam aspek keidupan sosial keagamaan.

Dalam ranah kehidupan sosial, aktivis Rohis terlihat lebih bersikap terbuka dan toleran-menerima kehadiran komunitas non muslim dalam kehidupannya seharihari baik sebagai pengajar ataupun hanya sebatas hidup bertetangga-maka dalam kehidupan keagamaan, aktivis Rohis terlihat memiliki kekhususan sikap. Mereka misalnya, tetap akan menolak jika jamaah Ahmadiyah tetap diberikan kebebasan beragama. Sikap ini setidaknya dipengaruhi oleh keyakinan mereka yang secara prinsip memang terlihat mengambil posisi berlawanan dengan keyakinan agama lain. Dalam konteks ini, mereka dengan tegas meyakini bahwa Islam merupakan agama paripurna. Yang oleh karena itu, berharap bahwa sistem Islam selain harus menjadi landasan dan panduan umum dalam bersikap dan berperilaku, juga sejatinya harus menjadi dasar kehidupan bernegara bangsa Indonesia. Secara politis, mereka berpandangan bahwa sistem pemerintahan Islam (khilafah islamiyah) pada giliraannya akan menjadi alternatif terbaik atas sistem demokrasi yang penuh kekurangan.

Keyakinan bahwa Islam seyogyanya menjadi sistem kenegaraan, alhasil membuat Rohis secara aktif memperjuangkan beberapa agenda keislaman di tingkatan sekolah. Seperti aksi penganjuran penggunaan rok panjang bagi para siswi (akhwat) dan celana panjang bagi siswa (ikhwan) di lingkungan sekolah, dan 
aksi-aksi lainnya (anti merokok, anti valentine day), menjadikan Rohis berhasil memainkan perannya sebagai sebuah representasi gerakan Islam kalangan pelajar.

\section{Rekomendasi}

Melihat pada sikap sosial keagamaan aktivis Rohis di SMA seperti kesimpulan tersebut di atas, walaupun sikap sosial keagamaan tersebut masih sebatas "semangat dalam beragama", tapi kiranya perlu disikapi dengan penuh perhatian agar semangat tersebut tidak kemudian menjurus dan berkembang kepada sikap dan perilaku yang radikal dalam menjalankan agamanya. Oleh Untuk itu, sebagai antisipasi berkembangnya sikap keberagamaan yang radikal di kalangan aktivis Rohis, khususnya di jenjang SMA, Direktorat Pendidikan Islam pada Ditjen Pendidikan Islam Kementerian Agama, perlu mengembangkan pendidikan agama berwawasan multikultural yang tidak hanya dapat diimplementasikan pada pembelajaran di kelas melalui kegiatan intrakurikuler PAI, juga mendorong kegiatan-kegiatan kajian keagamaan yang digagas dan dilaksanakan Rohis yang dapat menyemai sikap keagamaan yang toleran. Hal itu tidak hanya menjadi kepentingan Kementerian Agama, tapi juga pihak lainnya seperti Kementerian Pendidikan dan Kebudayaan, Pemerintah Daerah, serta sekolah dapat mengawal kegiatan keagamaan Rohis yang toleran.

Selain itu, perlu juga dilakukan penilaian melalui pengkajian mendalam yang dilakukan oleh Puslitbang Pendidikan Agama dan Keagamaan terhadap buku-buku teks dan buku-buku PAI lainnya yang bersifat pengayaan yang menjadi sumber bacaan peserta didik, terutama juga buku-buku yang dipergunakan aktivis Rohis di SMA yang dijadikan referensi permasalahan keagamaan. Perlu juga dihadirkan buku-buku bacaan keagamaan yang membawa pesan-pesan budaya damai berdasarkan local wisdom (kearifan lokal) yang ada pada masing-masing daerah.

Tak kalah pentingnya dari kedua rekomendasi tersebut di atas, para stakeholders perlu mendorong dan memfasilitasi terwujudnya dialog antar kelompok rohani peserta didik (kelompok rohani Islam, Kristen, Katolik, Hindu, dan Buddha) SMA agar dapat saling memahami perbedaan dan menghilangkan sekat-sekat komunikasi diantara mereka. Hal ini perlu dilakukan, dengan memahami bahwa sekolah merupakan miniatur kemajemukan masyarakat Indonesia.

\section{SUMBER BACAAN}

Alatas, Alwi \& Fifrida Desliyan, Revolusi Jilbab, Kasus Pelarangan Jilbab di SMA Negeri SeJabotabek, 1982-1991. Jakarta: Al-I'tishom, 2002

Ali, Fachry dan Effendy, Bahtiar. Merambah Jalan Baru Islam: Rekontruksi Pemikiran Islam Indonesia Masa Orde Baru. Bandung: Mizan, 1986.

Anwar, M. Syafi'i. Pemikiran dan Aksi Islam Indonesia: Sebuah Kajian Politik Tentang Cendekiawan Muslim Orde Baru. Jakarta: Paramadina, 1995.

Bubalo, Anthony \& Greg Fealy, Joining the Caravan, the Middle East, Islamism and Indonesia. Australia: Lowy Insitute for International Policy, 2005

Daminik, Said Ali. Fenomena Partai Keadilan, Transformasi 20 Tahun Gerakan Tarbiyah di Indonesia, Bandung: Teraju, 2002.

Effendy, Bahtiar. Islam Dan Negara: Transformasi Pemikiran dan Praktik Politik Islam di Indonesia. Jakarta: Paramadina, 2009

Emmerson, Donald $\mathrm{K}$, ed. Indonesia Beyond Soeharto: Negara, Ekonomi, Masyarakat, Transisi. Jakarta: PT. Gramedia, 2001.

Frans Husken, dkk, ed. Pembangunan dan Kesejahteraan Sosial: Indonesia Di Bawah Orde Baru. Jakarta: Grasindo, 1997. 
Hadijaya, ed. Kelas Menengah Bukan Ratu Adil. Yogyakarta: Tiara Wacana, 1999.

Jahroni, Jajang \& Jamhari, Gerakan Salafi Radikal di Indonesia. Jakarta: PT Raja Grafindo Persada, 2004.

Kuntowijoyo. Dinamika Sejarah Umat Islam Indonesia. Yogyakarta: Shalahuddin Press, 1994.

Latif, Yudi, Intelegensia Muslim dan Kuasa, Geneologi Intelegensia Muslim Indonesia Abad ke-2. Bandung, Mizan, 2005

Ricklefs, M. C. Sejarah Indonesia Modern 1200-2004. Penerjemah. Satrio Wahono, dkk, Jakarta: Serambi Ilmu Semesta, 2005.
Saleh, Fauzan. Teologi Pembaruan: Pergeseran Wacana Islam Sunni di Indonesia Abad 20. Jakarta: Serambi, 2004.

Thaba, Abdul Aziz, Islam dan Negara dalam Politik Orde Baru. Jakarta: Gema Insani Press, 1996

Woodward, R. Mark, Jalan Baru Islam, Memetakan Paradigma Mutakhir Islam Indonesia. Bandung: Mizan, 1998

Wahjosumidjo, Kepemimpinan Kepala Sekolah, Tinjauan Teoritik dan Permasalahannya. Jakarta: PT.RajaGrafindo Persada, 2007 